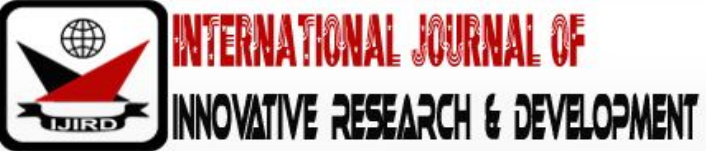

ISSN 2278 - 0211 (Online)

\section{Effect of Preventive Maintenance Practices and Supply Chain Management in Improving Manufacturing Performance}

D. Sasitharan
Ph.D. Student, School of Technology Management and Logistic,
University Utara Malaysia, Malaysia
Halim Mad Lazim
Associate Professor, School of Technology Management and Logistic,
University Utara Malaysia, Malaysia

\begin{abstract}
:
Preventive maintenance (PM) practices is well known strategy that still used by most manufacturing industry today. Basically (PM) has two type of practices namely Time-based maintenance (TBM) and condition-based maintenance (CBM) that help to minimize the equipment failure throughout planned and scheduled maintenance. On other hand the supply chain management (SCM) not only assist organizations production process such as (plan, control and execute a product's flow) but also ensure what are the growing need for companies in long-term. This study intent to examine how the (PM) practices and (SCM) increase the manufacturing performance in terms of: cost and delivery. Total One hundred and fifty-five Malaysian manufacturing companies participated in this study and the result indicates that the (PM) and (SCM) significantly improve the manufacturing performance but the impact is stronger for (SCM). Overall this study found that the (PM) practices are greater than (SCM) in traditional manufacturing in optimizing their end-to-end operations to achieve greater cost savings and product delivery.
\end{abstract}

Keyword: Manufacturing, preventive maintenance, supply chain management, cost, delivery

\section{Introduction}

The Malaysian government in its Vision 2050, envisaged a plan of bringing the manufacturing sector in pace with the developed countries (Ahmad and Ahmad, 2015; Aun, 2017). Despite this, there is no evidence that the Malaysian manufacturing sector has taken any initiatives to achieve this target by improving productivity. Though the majority of Malaysian firms are adopting policies and strategies to improve their performance, still it seems that there is no consensus on a strategic roadmap towards vision 2050 (Stuckler, Reeves, Karanikolos and McKee, 2015). Moreover Rasiah, Lin, et al. (2015) has pointed that that Malaysia unable to attract significant numbers of experts because currently it is facing increased competition from Singapore, Vietnam, Taiwan and China which make the Malaysia is still not prepare in facing global pressure. These global pressures raise to the arguments question of "what are the success factors that can leads the Malaysian manufacturing industry to improve their performance".

This study seeks to address key relationships between preventive maintenance (PM) and Supply chain Management (SCM)in improves the performance of Malaysian manufacturing industry. The reason why supply chain management (SCM) was employed in this study because, it enables companies to have better deal with inventory that keep costs to a minimum that creates efficiencies to meet customer demand (Fredendall and Hill, 2016). Meanwhile the preventive maintenance (PM) practices have two major component namely Time-based maintenance (TBM) and condition-based maintenance (CBM). It have been extensively studied in the context of manufacturing performance, as an evidence Jin, Siegel, et al. (2016); Muchiri, Pintelon, et al. (2014); Lee Siegel et al. (2013) has found the positive impact of (TBM) and (CBM) practices on manufacturing performance, specifically on cost reduction and enhanced production quality. In response to the statement above, this paper seeks to identify the linkage between preventive maintenance (PM) and supply chain management (SCM) to provide a clear picture of the relationships between them help in improves the performance of Malaysian manufacturing industry by reducing manufacturing cost and increase product quality.

\subsection{Objectives of Study}

- To examine effect of preventive maintenance practice son manufacturing performance.

- To examine the effect of Time-based Maintenance on manufacturing performance.

- To examine the effect of Condition-based Maintenance in improve manufacturing performance.

- To examine the effect of supply chain management on manufacturing performance.

- To examine the moderates the relationship of supply chain management and preventive maintenance practiceson manufacturing performance. 


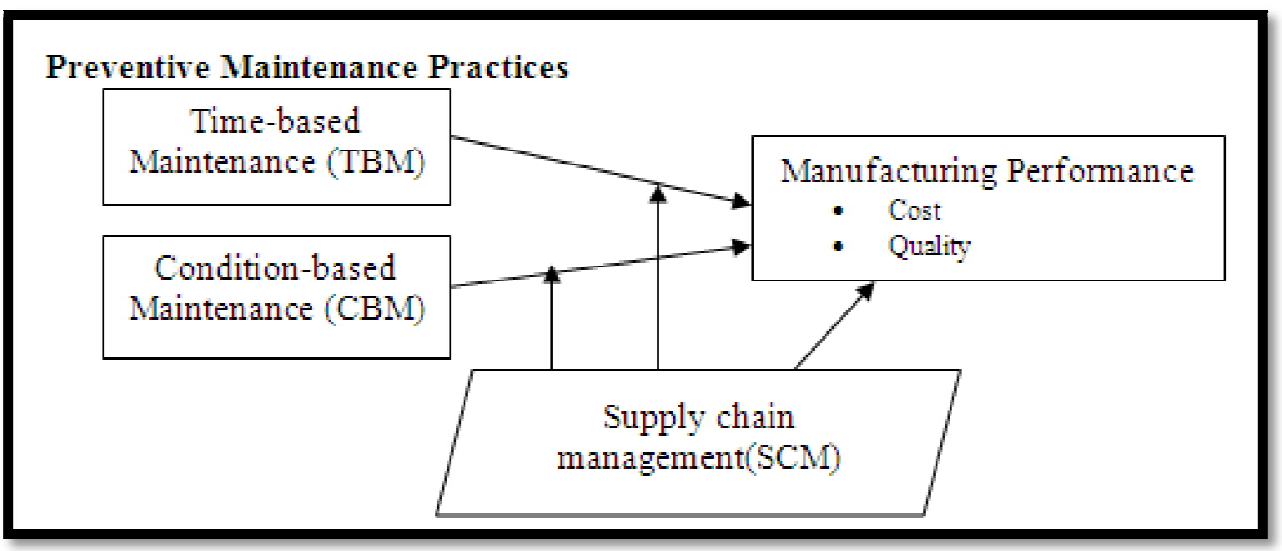

Figure 1: Theoretical Framework

\subsection{Hypothesis}

- H1: Time-based maintenance has significant relationship with of manufacturing performance.

- H2: Condition based maintenance has significant relationship with of manufacturing performance.

- H3: Supply chain management has significant relationship with of manufacturing performance.

- H4: Supply chain management moderates the relationship of (TBM) in improve the manufacturing performance.

- H5: Supply chain management moderates the relationship of (CBM) in improve the manufacturing performance.

\section{Literature Review}

Preventive maintenance is one of the widespread maintenance activities that have been apply by many industries. Basically, preventive maintenance classified as predetermined/ periodic or Condition-based maintenance. The intention of preventive maintenance is to avoid the failure of equipment's, prevent the costs of breakdown and reduce of downtime (Aghezzaf, Khatab, et al. 2016). On other hand the supply chain is defined as a set of three or more organisations directly involved in the flow of products or services to the ultimate consumer (Christopher, 2016). Ross, (2015) stated that the essence of integrated supply chain management is supply chain planning and control, which has additional role in contribute necessity action in produce low cost manufacturing process that help to increase the profit margins. This was agreed by Leonidou, Fotiadis, et al. (2015), were competitive advantage could be achieved by embracing the cost leadership that focused on low cost relative to the competitors, related and standardized products, and scale economy. Meanwhile Juran, (1974) defined quality as "fitness for use". This definition designed based on the customer's perspective in defining the quality. On other word Gera, Mittal, et al. (2017) described quality as the customer satisfaction; decision or requirement toward the goods or services that their needs.

\section{Methodology}

This study uses quantitative approach to collect data.A structured questionnaire was distributed to Malaysia manufacturers that operate in Peninsular Malaysia. Smart PLS the questionnaire is purposely designed to extract detail of; how the (PM) practices and (SCM) improve manufacturing performance by reducing production cost and increase product quality. The questionnaire was sent through the email and postal letters. As representing the manufacturing companies, the questionnaires were responded by the managers as well as various engineers that directly contributed with manufacturing plant operation. From 600 questionnaire were sent only 155 questionnaires was received and the response rate was 25 per cent. According to Jasti and Kurra (2017) 23\% response rate was consider good response rate for the circumstances of the mailed survey from manufacturing firms. Thus, this ready study conducts further analysis to extract information from response rate. The 5-point Likert scale was used to measure the response rate as well as response quality.This study used Smart PLS 3 software to analyse following hypotheses.

\section{Data Analysis and Results}

\subsection{Measurement Model Assessment}

In conducting the Smart (PLS)analysis's it necessary to conduct two analysisit was measurement and structural model assessment. First was we measured the structural model assessment where the researcher will examine the Cronbach alpha; composite reliability average variance extracted (AVE); factor Loading value of each items and variables. Figure 1 below illustrates the summary of measurement model assessment of this study. The overall analysis indicates that all the values are under acceptable range. Factor loading is above 0.7 , Cronbach alpha and composite reliability also above 0.7. Furthermore, average variance extracted (AVE) is more than 0.5 which attain the convergent validity. 


\begin{tabular}{|c|c|c|c|c|c|}
\hline Construct & Indicators & Loadings & Cronbach Alpha & Composite Reliability & $\overline{\text { AVE }}$ \\
\hline $\begin{array}{l}\text { Time-based } \\
\text { Maintenance } \\
\text { (TBM) }\end{array}$ & $\begin{array}{l}\text { TBM1 } \\
\text { TBM2 } \\
\text { TBM3 } \\
\text { TBM4 }\end{array}$ & $\begin{array}{l}0.883 \\
0.919 \\
0.894 \\
0.900 \\
\end{array}$ & 0.921 & 0.994 & 0.808 \\
\hline $\begin{array}{l}\text { Condition-based } \\
\text { maintenance } \\
\text { (CBM) }\end{array}$ & $\begin{array}{l}\text { CBM1 } \\
\text { CBM2 } \\
\text { CBM3 } \\
\text { CBM4 }\end{array}$ & $\begin{array}{l}0.871 \\
0.866 \\
0.870 \\
0.845\end{array}$ & 0.886 & 0.921 & 0.745 \\
\hline $\begin{array}{l}\text { Supply Chain } \\
\text { Maintenance } \\
\text { (SCM) }\end{array}$ & $\begin{array}{l}\text { SCM1 } \\
\text { SCM2 } \\
\text { SCM3 } \\
\text { SCM4 } \\
\text { SCM5 }\end{array}$ & $\begin{array}{l}0.926 \\
0.849 \\
0.910 \\
0.820 \\
0.924\end{array}$ & 0.932 & 0.948 & 0.787 \\
\hline $\begin{array}{c}\text { Manufacturing } \\
\text { performance } \\
\text { (MP) } \\
\text { Cost (C); Quality } \\
\text { (Q) }\end{array}$ & $\begin{array}{l}\text { C1 } \\
\text { C2 } \\
\text { C3 } \\
\text { C4 } \\
\text { C5 } \\
\text { Q1 } \\
\text { Q2 } \\
\text { Q3 } \\
\text { Q4 } \\
\text { Q5 }\end{array}$ & $\begin{array}{l}0.812 \\
0.880 \\
0.895 \\
0.898 \\
0.924 \\
0.780 \\
0.890 \\
0.922 \\
0.905 \\
0.858\end{array}$ & 0.966 & 0.971 & 0.770 \\
\hline
\end{tabular}

Table 1: Factor Loading, Reliability, Convergent Validity, AVE

Table 1 above show the summary of measurement model of this study. Refer to table 1 we can see that result of factor loading value of all measurement items which show satisfaction value more than 0.7 . On other handthe composite reliability and Cronbach alpha value ofTBM; CBM and MP is more than $\mathrm{p}>0.5$ were in range between $0.886-0.994$. Meanwhile the Average variance extracted (AVE) value for TBM; CBM and MP is more than 0.5 which in range of 0.770 0.994 that confirms all measurement models fulfil the appropriate value to conduct further analysis.

\subsection{Structural Model Assessment}

According to Hair et al. (2018) the structural model analysis only can conduct after the measurement model observed. These because the structural model analysis basically examines the in direct and direct effect of hypotheses were the researcher will weather to acceptance and omit the hypotheses based on P-value. After complete structural model analysis, the moderating analysis will be tested. Table 2 and 3 below shows the complete structural model assessment.

\begin{tabular}{|c|c|c|c|c|c|c|c|}
\hline Hypotheses & Relationship & $\begin{array}{c}\text { Original } \\
\text { Sample } \\
\text { (0) }\end{array}$ & $\begin{array}{c}\text { Sample } \\
\text { Mean } \\
\text { (M) }\end{array}$ & $\begin{array}{c}\text { Standard } \\
\text { Deviation } \\
\text { (STDEV) }\end{array}$ & $\begin{array}{c}\text { T Statistics } \\
(\mid \mathbf{O} / \text { STDEV|) }\end{array}$ & $\begin{array}{c}\mathbf{P} \\
\text { Values }\end{array}$ & Decision \\
\hline H1 & TBM- $>$ MP & 0.504 & 0.485 & 0.161 & 3.124 & 0.002 & Supported \\
\hline H2 & CBM- $>$ MP & 0.110 & 0.165 & 0.191 & 0.577 & 0.564 & Rejected \\
\hline H3 & SCM->MP & 0.283 & 0.251 & 0.152 & 1.866 & 0.063 & Rejected \\
\hline
\end{tabular}

Table 2: Direct Hypotheses Results

Table 2 indicates the results of inner model in which show the direct hypotheses result for (TBM); (CBM) and (SCM) variables toward (MP). Overall result the direct hypotheses results indicates that only (TBM) show significant effect on $(\mathrm{MP})$ were the $\mathrm{P}$-value of TBM- $>\mathrm{MP}$ was $0.002(\mathrm{p}<0.05)$. However, the $(\mathrm{CBM})$ and $(\mathrm{SCM})$ fail to show insignificant relationship on (MP) were the $p$-value of $(\mathrm{CBM})$ and $(\mathrm{SCM})$ is more than $(\mathrm{p}<0.05)$. Thus,this study declares thathypothesesH1 supported and (H2 and $\mathrm{H} 3$ ) rejected.

\begin{tabular}{|c|c|c|c|c|c|c|c|}
\hline Hypotheses & Relationship & $\begin{array}{c}\text { Original } \\
\text { Sample (0) }\end{array}$ & $\mathbf{( M )}$ & $\mathbf{\text { (STDEV) }}$ & $\begin{array}{c}\text { T } \\
\text { Statistics }\end{array}$ & $\begin{array}{c}\text { P } \\
\text { Values }\end{array}$ & Decision \\
\hline H4 & TBM - >SCM ->MP & -0.060 & -0.019 & 0.117 & 0.511 & 0.609 & Rejected \\
\hline H5 & CBM - SSCM->MP & 0.154 & 0.107 & 0.162 & 0.953 & 0.341 & Rejected \\
\hline
\end{tabular}

Table 3: Moderation Effect

Table 3 illustrate the moderation results for hypothesis (H4 and H5). Hair et al. (2016)stated that the minimum acceptance level is(t-value 1.96)and the significance level to accept the hypothesis is should be equal to or less ( $\mathrm{p}<0.05$ ). Therefore, refer to table 3 the moderation analysis for H4andH5 insignificant $t$-value were for (TPB $=t<0.511$ at $p>0.609$ ) 
and $(\mathrm{CBM}=\mathrm{t}<0.341$ at $\mathrm{p}>0.341)$ were both $(\mathrm{t}>1.96)$ and $\mathrm{p}$-value at unsatisfactory level. Therefore, this study finalise that there is no moderation relationship between TBM and CBM toward Supply chain management in improve the manufacturing performance.

\section{Discussion}

Based on overall result of the study this paper found that only (TBM) show significant effect on manufacturing performance were the $\mathrm{p}$ - value of (TBM) $(\mathrm{p}<0.002)$. There are total five hypotheses and form those hypotheses only one hypothesis was accepted it was H1: "Time-based maintenance has significant relationship with of manufacturing performance". Meanwhile the rest four hypotheses were rejected due to in significant $p$ and $t$ value. The results of this study support previous research conducted by Bajestani and Beck, (2015) time-based maintenance (TBM) appropriate for all production plant where it help to avoid the machine failure which sufficient to meet organization demand. In meantime the preventive maintenance strategy can be applicable for both maintenance and production decisions these because it can decide the maintenance decisions independently based on analysing the state of the machines such as age and characteristics of the equipment that will resulted static rules De Jonge, Teunter, et al. (2017).

\section{Conclusion}

This study concludes that CBM and (SCM) has no significant effect in improve the manufacturing performance. This means the respondents of this study (Malaysian manufacturing companies) deny the (CBM) and (SCM) implementation in manufacturing plant not sustainably optimise the resources in reduce the cost and increase the product quality. Therefore, this study summarises that the (TBM) become an attractive technique among Malaysian manufacturing sector to retain assets. Overall this study concludes that the preventive maintenance (PM) practices become proactive approach among Malaysian manufacturing sector to minimize the machine breakdown that extended their product quality and minimise plant operating costs.

\section{References}

i. Aghezzaf, E.-H., Khatab, A., \& Le Tam, P. (2016). Optimizing production and imperfect preventive maintenance planning' $s$ integration in failure-prone manufacturing systems. Reliability engineering \& system safety, 145, 190198.

ii. Ahmad, A. N., Rahman, A. A., \& Ab Rahman, S. (2015). Assessing knowledge and religiosity on consumer behavior towards halal food and cosmetic products. International Journal of Social Science and Humanity, 5(1), 10.

iii. Aun, L. H. (2017). Malaysia's Transformasi Nasional 2050 Brings Bold New Style, but to What End?

iv. Bajestani, M. A., \& Beck, J. C. (2015). A two-stage coupled algorithm for an integrated maintenance planning and flowshop scheduling problem with deteriorating machines. Journal of Scheduling, 18(5), 471-486.

v. Christopher, M. (2016). Logistics \& supply chain management: Pearson UK.

vi. De Jonge, B., Teunter, R., \& Tinga, T. (2017). The influence of practical factors on the benefits of condition-based maintenance over time-based maintenance. Reliability engineering \& system safety, 158, 21-30.

vii. Fredendall, L. D., \& Hill, E. (2016). Basics of supply chain management: CRC Press.

viii. Gera, R., Mittal, S., Batra, D. K., \& Prasad, B. (2017). Evaluating the effects of service quality, customer satisfaction, and service value on behavioral intentions with life insurance customers in India. International Journal of Service Science, Management, Engineering, and Technology (IJSSMET), 8(3), 1-20.

ix. Hair Jr, J. F., Hult, G. T. M., Ringle, C., \& Sarstedt, M. (2016). A primer on partial least squares structural equation modeling (PLS-SEM): Sage Publications.

x. Jasti, N. V. K., \& Kurra, S. (2017). An empirical investigation on lean supply chain management frameworks in Indian manufacturing industry. International Journal of Productivity and Performance Management, 66(6), 699723.

xi. Jin, X., Siegel, D., Weiss, B. A., Gamel, E., Wang, W., Lee, J., \& Ni, J. (2016). The present status and future growth of maintenance in US manufacturing: results from a pilot survey. Manufacturing review, 3.

xii. Juran, J. M. (1974). Basic concepts. Quality control handbook, 2.

xiii. Lee J., Siegel D., \& Lapira ER. (2013). Development of a Predictive and Preventive Maintenance Demonstration System for a Semiconductor Etching Tool. ECS Transactions. ;52(1):913-927.

xiv. Muchiri, P. N., Pintelon, L., Martin, H., \& Chemweno, P. (2014). Modelling maintenance effects on manufacturing equipment performance: results from simulation analysis. International Journal of Production Research, 52(11), 3287-3302.

xv. Rasiah, R. Lin, Y., \& Muniratha, A. (2015). The Role of the Diaspora in Supporting Innovation Systems: The Experience of India, Malaysia and Taiwan Emerging Economies (pp. 353-373): Springer.

xvi. Reason, J. (2016). Managing the risks of organizational accidents: Routledge.

xvii. Stuckler, D., Reeves, A., Karanikolos, M., \& McKee, M. (2015). The health effects of the global financial crisis: can we reconcile the differing views? A network analysis of literature across disciplines. Health Economics, Policy and Law, 10(1), 83-99. 